\title{
Allergic risk assessment of genetically modified cucumber mosaic virus resistant pepper
}

\author{
Dae-Yeul Son* \\ Department of Food and Biotechnology, Daegu Haany University, Gyeongsan 38610, Korea
}

\section{유전자변형 바이러스 저항성 고추의 알레르기 안전성}

\author{
손대열* \\ 대구한의대학교 바이오산업융합학부
}

\begin{abstract}
Genetically modified (GM) pepper H15 containing the gene for cucumber mosaic virus (CMV) coat protein (CP) and its control line non-GM pepper P2377 were investigated for their allergic risk. Amino acid sequence of the inserted gene product CMV-CP was compared with those of known allergens. No known allergen had greater than $35 \%$ amino acid sequence homology over an 80 amino acid window or more than 8 consecutive identical amino acids. Protein patterns of GM and non-GM pepper extracts were evaluated by SDS-PAGE, which showed similar distribution of protein bands for both GM and non-GM pepper. Antigen-antibody reactions were compared between GM and its non-transgenic parental control. ELISA and immunoblot analysis of sera from allergic patients showed some IgE reactivity; however, no differences were observed between GM pepper H15 and P2377. We therefore conclude that CMV-CP is less likely to be an allergen; the protein composition and allergenicity of the GM pepper H15 is not different from that of P2377 and safe as a commercial host.
\end{abstract}

Key words : CMV resistant, safety assessment, allergenicity

\section{서 론}

유전자변형 작물 개발은 1980 년대부터 시작되었으며, 1994년에 잘 물러지지 않는 연화 지연 토마토 Flavr Savr ${ }^{\circledR}$ 가 시판되면서 일반인들의 유전자변형 식품에 대한 관심이 고조되었고, 미국 몬산토사가 1995년 제초제 저항성 유전 자변형 콩을 상품화하면서 유전자변형 작물의 상용이 전 세계적으로 본격화되었다.

유전자변형 작물의 인체 및 환경에 미치는 영향과 안전 성에 관한 논의는 1990 년 $\mathrm{FAO}$ 와 $\mathrm{WHO}$ 의 주관 하에 미국, 일본, 영국을 포함한 9개국과 정책협의로 시작되었으며, 분자 생물학적 특성, 발현형태학적 특성 및 독성 물질과

*Corresponding author. E-mail : dyson@dhu.ac.kr

Phone : 82-53-819-1434, Fax : 82-53-819-1272

Received 24 September 2015; Revised 3 November 2015; Accepted 4 November 2015.

Copyright (c) The Korean Society of Food Preservation. All rights reserved.
영양 조성성분의 관점에서 기존 식품과의 실질적 동등성을 규명하는 것이 안전성 평가의 기본 원칙이다(1). 이 후 유전 자변형 작물 개발이 활발한 국가를 주축으로 유전자변형 작물의 안전성을 규제하는 장치들이 고안되고 있다. 미국 의 경우 $\mathrm{FDA}$ 산하의 생명과학 평가 팀이 발족되어 관련 법규에 따른 안전성 평가를 전담하고 있다. 일본에서는 보 건 후생성에 유전학, 식품학, 면역학, 독성학 등의 각 분야 전문가와 행정가가 포함된 특별위원회가 이러한 역할을 담당하며, 이는 유럽 연합에서도 유사하다.

국내에서도 유전자변형 작물의 유입이 증가함에 따라 2000년 제초제 내성 콩에 대한 최초의 안전성 심사가 완료 된 이래 2001년 7월에 식품위생법에 따라 유전자변형 식품 의 표시의무화가 시행되었고, 2002년 8월에 식품위생법 제 15 조 안전성평가 등 관련 조항이 신설 개정, 고시된 이래 2004년 2월 27일 유전자변형 식품의 안전성 심사 의무화가 법으로 시행되면서 안전성심사가 이루어지지 않으면 관련 제품의 판매가 금지되고 있다. 이러한 유전자변형 식품의 안전성 심사 의무화가 추진된 배경은 새로운 유전자변형 
작물의 개발 및 상품화가 급증하면서 그 안전성에 대한 일반 소비자의 불안감이 해소되지 않기 때문이다. 안전성 심사에서 평가되는 항목은 숙주, 공여체, 벡터, 유전자, 영 양, 독성, 알레르기성 등이며 식품의약품안전처가 정하는 항목 중 어떠한 항목이라도 안전성을 증명하지 못하면 안전 성 심사가 이루어지지 못해 국내 유통이 불가능하다. 현재 전 세계에서 유통되고 있는 유전자변형 농산물 중에서 우리 나라 식품의약품안전처에서 안전성 심사가 완료된 것은 2015년 7월 31일 기준 총 131건(Table 1)이며 국내에서 개발 되어 상품화된 유전자변형 농산물은 아직 없다. 국내에서 도 생물공학 산업의 육성을 위하여 많은 투자가 이루어져 유전자변형 작물이 연구 개발되고 있으며, 머지않아 다양 한 작물이 상업화 될 것이다.

지금까지 유전자변형 식품에 의해 알레르기가 발생되었 다는 보고는 없으며, 새로운 유전자변형 식품의 알레르기 유발 가능성은 주로 삽입 단백질이 이미 알려져 있는 알레 르겐과 상동성이 있는가(2,3) 열처리에 대한 민감성(4) 또는 인공 위/장액 조건에서 잘 분해되는가를 판단함(5,6)으로 이루어지고 있으며, 그 외에 알레르기 환자 IgE 항체와의 반응성이 조사됨으로 판단된다. 현재 국내에서 유전자변형 식품에 대한 과학적이고 체계적인 알레르기 유발 가능성에 대한 연구 발표는 미미한 상태이다.

고추(Capsicum annuum)는 우리나라에서 풋고추, 고춧가 루 및 고추장의 주재료로 이용되는 중요한 채소작물 중 하나로써(7) 비타민 $\mathrm{A}$ 와 $\mathrm{C}$ 가 풍부한 중요한 영양원이며, 항암성이 있는 것으로 알려져 있다(8). 우리나라에서 매년 총 35 만톤 이상의 고추가 생산되고 있지만, 고추에 발생하 는 다양한 병충해, 특히 바이러스에 의한 피해는 경제적으 로 막대한 것으로 알려져 있다 $(7,9,10)$. 그 중 cucumber mosaic virus(CMV)는 세계적으로 9 과 100 여종의 식물에

Table 1 . Genetically modified products approved by the Korean Food and Drug Administration (2015. 7. 31)

\begin{tabular}{ccc}
\hline & Products & Approved \\
\hline Soybean (20) & Single trait product & 15 \\
& Combined trait product & 5 \\
Corn (69) & Single trait product & 23 \\
& Combined trait product & 46 \\
Cotton (23) & Single trait product & 12 \\
& Combined trait product & 11 \\
Canola (13) & Single trait product & 10 \\
Sugar beet (1) & Combined trait product & 3 \\
Potato (4) & Single trait product & 1 \\
Alfalfa (1) & Single trait product & 4 \\
\hline
\end{tabular}

모자이크 병징을 나타내는 주된 바이러스로 알려져 있다 (7,9,11-13). 이에 본 연구는 Agrobacterium을 이용한 형질전 환법을 통해 전 세계적으로 고추에 병을 일으키는 대표적인 원인 바이러스인 CMVP0로 알려진 FNY-CMV strain 유래 의 coating protein $(\mathrm{CP})$ 유전자가 형질전환 됨으로써 $\mathrm{CMV}$ 에 저항성을 나타내도록 개발된 고추 계통 H15(14)와 그 모식물(P2377)을 재배하여 GM작물의 알레르기 유발 가능 성을 비교 검증하고자 하였다.

\section{재료 및 방법}

재 료

실험에 사용된 고추는 농우바이오(주)에서 CMV-CP 유 전자를 형질 전환하여 개발된 $\mathrm{CMV}$ 내병성 고추 계통인 $\mathrm{H} 15$ 와 그 모식물(대조구) P2377이며, 중부지역(경기도 안 성시 소재의 중앙대학교 산업과학대학 농장 내에 위치한 $\mathrm{GMO}$ 격리포장)과 북부지역(경기도 남양주시 소재의 고려 대학교 부속 덕소 농장의 $\mathrm{GMO}$ 격리포장)에서 재배되었다.

\section{환자혈청}

설문을 통해 알레르기가 있다고 응답한 7명의 농우바이 오(주) 연구소 종사자의 혈청을 이용하여 immunoblotting 및 ELISA 실험을 진행하였으며, 확보된 혈청은 $-20^{\circ} \mathrm{C}$ 에 보관 사용하였다. 혈청을 제공한 7명은 34 48세의 연령대 로 남성 6 명 여성 1 명이었으며, 모두 꽃가루에 알레르기가 있는 것으로 응답하였고, 그 중 2 명은 꽃가루 외에 곰팡이와 집먼지 진드기에 대해서도 알레르기가 있다고 응답하였다. 확보된 혈청에 대한 $\mathrm{CAP}$ 측정은 이루어지지 않았다. 혈청 중 immunoblotting 검사 후 ELISA 검사를 진행하기에 양이 충분하지 못한 혈청은 ELISA 검사에서 제외되었다.

\section{단백질 농도측정}

각 샘플에서 추출된 단백질 농도는 Bradford법(15)에 의 해 정량되었고, 시약은 상업적으로 판매되는 $\mathrm{Bio}-\mathrm{Rad}$ (Hercules, CA, USA)사에서 구입한 protein assay kit를 이용 하여 $495 \mathrm{~nm}$ 에서 흡광도를 측정하여 표준 용액과 농도를 비교하여 측정하였다.

\section{단백질 전기영동 및 immunoblotting}

단백질 전기영동은 Laemmli 방법(16)에 준하여 단백질 을 변성시킨 조건에서 실시하였다. $13 \%$ 의 separation gel을 미리 설치된 전기영동용 glass plate에서 중합시킨 후 그 위에 $4.5 \%$ 의 stacking gel을 중합시켰다. 준비된 젤은 전기 영동 완충용액 $(25 \mathrm{mM}$ Tris, $192 \mathrm{mM}$ glycine, $0.1 \% \mathrm{SDS}$ )가 들어있는 전기영동조에 설치하고, 샘플 완충용액 $(60 \mathrm{mM}$ Tris/HCl(pH 6.8), 25\% glycerol, 2\% SDS, 14.4 mM 2- 
mercaptoethanol, $0.1 \%$ bromphenol blue)와 시료를 1:5로 혼 합 후 $100^{\circ} \mathrm{C}$ 에서 5 분간 중탕 가열하여 시료로 사용하였다. 전기영동은 우선 100 볼트에서 10 분간 시행하여 시료가 stacking gel에 진입한 후 200 볼트에서 35 분 추가로 전기영 동 하였다. 전기영동 후 $\mathrm{gel}$ 은 단백질 확인을 위해 Coomassie 용액(1 g Coomassie Blue R-250, $450 \mathrm{~mL}$ methanol, $450 \mathrm{~mL} \mathrm{H} \mathrm{H}_{2} \mathrm{O}, 100 \mathrm{~mL}$ glacial acetic acid)으로 착색 하거나 polyvinylidene fluoride(PVDF) membrane으로 단백 질을 전사하는데 사용하였다. 전기영동을 통해 $\mathrm{gel}$ 상에서 분리된 단백질은 PVDF membrane으로 전사용 완충용액(20 $\mathrm{mM}$ glycin, $25 \mathrm{mM}$ Tris, $20 \%$ methanol)에 침수된 상태에서 $\mathrm{Bio}-\operatorname{Rad}(\mathrm{Hercules}, \mathrm{CA}, \mathrm{USA}$ )사의 장비를 이용하여 100 볼 트에서 1시간 전사하였다. 전사 완료된 PVDF membrane은 항혈청과의 반응성 조사에 앞서 비특이적 반응부위를 차단 하기 위해 $2 \%$ non fat dried milk(NFDM)와 $0.3 \%$ Tween 20 이 포함된 PBS(NFDM/PBST)용액으로 30분간 blocking 한 후 $1: 20$ 으로 희석된 환자혈청과 16 시간 $\left(4^{\circ} \mathrm{C}\right)$ 반응시켰 다. 결합하지 않은 $\mathrm{IgE}$ 는 PBST를 이용하여 3 번 세척한 후, 결합된 $\mathrm{IgE}$ 의 확인을 위해 $1: 4000$ 으로 희석된 biotin-goat polyclonal IgG-anti-human IgE(KPL, Gaithersburg, MD, USA)와 실온에서 1시간 반응시켰다. 다시 PBST를 이용하 여 3번 세척한 후 1:3000으로 희석된 StreptAvidin$\mathrm{APO}(\mathrm{Bio}-\mathrm{Rad}$ \#170-3554, Hercules, CA, USA)과 실온에서 1시간 반응시키고 다시 PBST를 이용하여 3번 세척 후 색반 응을 일으켜 반응한 단백질을 시각화하였다.

\section{ELISA}

Microtiter plate(NUNC polysorb)에 $1 \mu \mathrm{g} / \mathrm{mL}$ 농도의 항원 을 well 당 $200 \mu \mathrm{L}$ 씩 분주하고 $4{ }^{\circ} \mathrm{C}$ 에서 16 시간 고정시킨 후 PBST로 세척하고 $2 \% \mathrm{NFDM}$ 가 포함된 PBST 용액으로 blocking 하였다. 환자혈청을 1:20으로 희석하여 well 당 $100 \mu \mathrm{L}$ 씩 분주하고 $37^{\circ} \mathrm{C}$ 에서 3 시간 반응시킨 후 PBST 용액 으로 3회 세척하였고, 1:4000으로 희석된 biotinylated goat anti-IgE(KPL, Gaithersburg, MD, USA)와 실온에서 1시간 반응시켰다. 다시 PBST 용액으로 3회 세척 후 1:8000으로 희석된 NeutrAvidin-HRP(Pierce Biotechnology, Rockford, $\mathrm{IL}, \mathrm{USA})$ 와 실온에서 1 시간 반응시켰다. 세척 후 기질용액 (0.01\% 3,3',5,5'-tetramethyl-benzidine) $100 \mu \mathrm{L} / \mathrm{well}$ 을 첨가 하여 색반응을 일으키고, 일정 시간 후 $6 \mathrm{~N}$ 의 황산용액 $50 \mu \mathrm{L}$ 씩 첨가하여 색 반응을 정지시킨 후 $450 \mathrm{~nm}$ 에서 흡광 도를 측정하였다.

\section{결과 및 고찰}

알레르겐 $\mathrm{DB}$ 를 이용한 기존 알레르겐과의 상동성 비교 도입단백질의 잠재적 알레르기성 평가에 관한 Codex 지
침(17)에 따르면 도입단백질이 알레르겐과 80개씩의 아미 노산 단편 비교에서 $35 \%$ 보다 큰 아미노산 상동성을 가질 경우 도입단백질은 기지의 알레르겐과 알레르기성 교차반 응성이 존재할 수도 있다고 제시한다. 또한 아미노산 서열 이 잠재적인 알레르겐의 에피토프와 8 개 이상 직선으로 연속된 아미노산에 대해 정확한 서열 상동성을 가질 경우 알레르기 가능성이 있을 수 있다고 보고되었다 $(2,18)$. Codex 지침에 따라 삽입 유전자 CMV-CP로부터 유추된 아미노산의 염기서열과 기존에 알려진 알레르겐과의 염기 서열 상동성 검색은 The Food Allergy Research and Resource Program(FARRP) AllergenOnline(http://www. allergenonline.org, last updated: January 12, 2015)과 Structural Database of Allergenic Proteins(SAAP, last updated: February 25, 2013) 프로그램을 이용하여 기존에 알려진 알레르기 유발 물질과 각각 80 개씩의 아미노산에 대한 상동성 비교를 통하여 $35 \%$ 보다 큰 상동성을 갖는 알레르겐의 존재 유무와 8 개 이상의 연속된 아미노산이 일치하는 알레르겐의 존재유무를 검색하였다.

총 218 개의 아미노산으로 구성된 CMV-CP 염기서열을 80 개씩의 단위로 총 139 번의 비교가 이루어졌으며, 그 결과 가장 높은 상동성을 보인 알레르겐은 80 개씩의 아미노산 비교에서 26 개의 아미노산이 일치해서 $32.5 \%$ 의 상동성을 나타낸 선충(Anisakis simplex) 유래 Ani s 4 이었다(Fig. 1). 두 번째로 높은 상동성이 확인된 알레르겐은 땅콩(Arachis

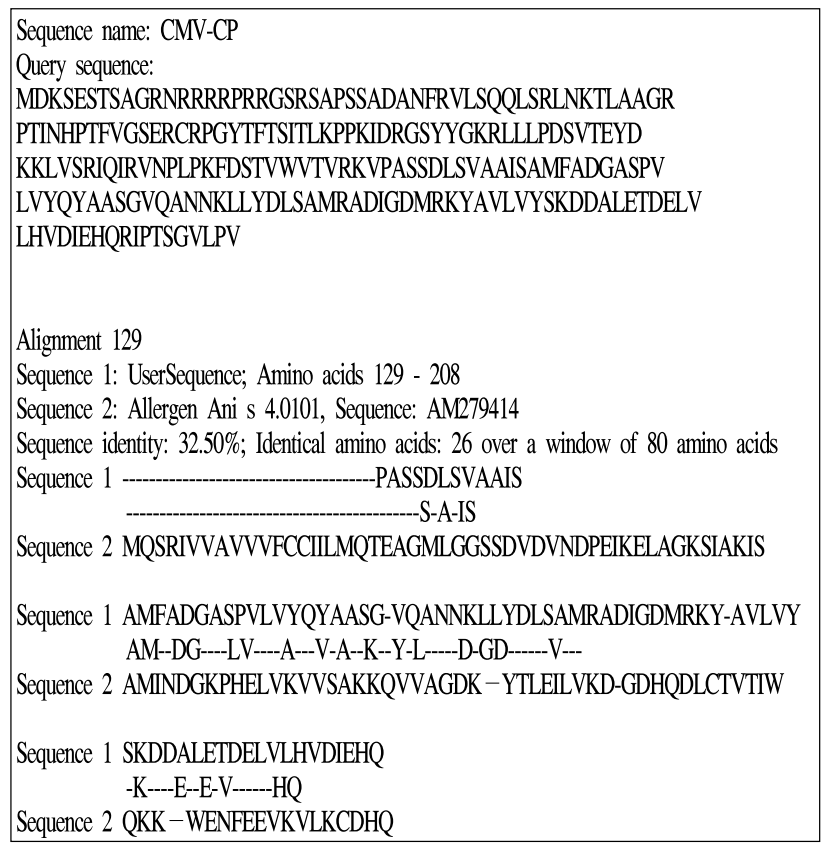

Fig. 1. CMV-CP sequence and the result of FASTA alignments for an 80 amino acids sliding window performed using the SDAP allergens database.

Cross-reactivity between a query protein and a known allergen has to be considered when there is more than $35 \%$ identity in the amino acid sequence of the query protein, using a window of 80 amino acids and a suitable gap penalty. 
Table 2. Comparison of protein contents ( $\mu \mathrm{g}$ per $\mathrm{mL}$ ) of GM pepper and its non-transgenic parental control grown in 2 different areas of Korea

\begin{tabular}{ccccc}
\hline \multirow{2}{*}{ Cultivars } & \multirow{2}{*}{ Cultivated area } & \multicolumn{3}{c}{ Cultivated in } \\
\cline { 3 - 5 } & & 2008 & 2009 & 2010 \\
\hline nonGM (P2377) & Ansung & $311 \pm 5.6^{\mathrm{Al}}$ & $325 \pm 3.0^{\mathrm{C}}$ & $164 \pm 2.0^{\mathrm{B}}$ \\
& Dukso & $390 \pm 7.2^{\mathrm{C}}$ & $350 \pm 5.6^{\mathrm{D}}$ & $148 \pm 2.6^{\mathrm{A}}$ \\
\multirow{3}{*}{ GM (H15) } & Ansung & $300 \pm 6.2^{\mathrm{A}}$ & $256 \pm 4.4^{\mathrm{B}}$ & $207 \pm 4.0^{\mathrm{C}}$ \\
& Dukso & $370 \pm 7.0^{\mathrm{B}}$ & $240 \pm 4.4^{\mathrm{A}}$ & $230 \pm 4.6^{\mathrm{D}}$ \\
\hline
\end{tabular}

${ }^{1)}$ All values are the mean $\pm \mathrm{SD}$ of triplicate determinations. Values with different superscripts within the same column are significantly different at $p<0.05$ by Duncan's multiple range test.

hypogaea)에서 유래하는 알레르겐 Ara h 8(80개 중 23개의 아미노산 염기서열이 일치, $28.75 \%$ 상동성)이었으며, 알레 르겐 Ani s 4와 Ara h 8에 이어 세 번째로 상동성이 높은 알레르겐은 80 개의 아미노산 염기서열 중 17 개의 아미노산 염기서열이 일치하는 유럽 집먼지진드기(Dermatophagoides pteronyssinus)에서 유래하는 Der p 8 알레르겐으로 $21.25 \%$ 의 염기서열 상동성이 확인되었다(Table 3). 기존 알려진 알레르겐과 8 개 또는 7개의 연속된 아미노산 염기서열이 일치하는 알레르겐은 존재하지 않았으며, 6 개의 연속된 아 미노산 염기서열이 일치하는 알레르겐은 총 5 종류(곰팡이 Malassezia sympodialis 유래 Mala s 9, 콩 Glycine max Gly $\mathrm{m}$ 6.0501와 Gly m 6.0401, 곰팡이 Cladosporium herbarum 유래 Cla h 9.0101, 쑥 Artemisia vulgaris 유래 Art v 6.0101) 가 확인되었다. 이상의 결과를 통해 $\mathrm{CMV}$ 바이러스 저항성 $\mathrm{H} 15$ 고추 도입유전자의 발현산물인 CMV-CP 단백질의 80 개씩의 아미노산 비교에서 $35 \%$ 보다 큰 상동성을 갖거나 8 개 이상의 일련된 아미노산 염기서열이 일치하는 알레르 겐은 존재하지 않는 것이 확인되었으며, 따라서 CMV-CP 단백질 서열은 기지의 알레르겐과 구조적 및 면역학적으로 연관된 유사성이 없음을 확인하였다.

Table 3. Most relevant records of similarity search of allergen protein sequence

\begin{tabular}{ccccc}
\hline Allergen & Organism & $\begin{array}{c}\text { Accession } \\
\text { no. }\end{array}$ & $\begin{array}{c}\text { Identity } \\
(\%)\end{array}$ & Description \\
\hline Ani s 4 & Anisakis simplex & AM279414 & 32.5 & Nematode allergen \\
Ara h 8 & Arachis hypogaea & EF436550 & 28.75 & Peanut allergen \\
Der p 8 & $\begin{array}{c}\text { Dermatophagoides } \\
\text { pteronyssinus }\end{array}$ & P46419 & 21.25 & House dust mite allergen \\
\hline
\end{tabular}

\section{추출된 고추 단백질 항원 비교}

지역 및 조건에 따른 단백질 항원을 비교하기 위해 유전 자 변형 고추와 그 모본은 우리나라 중부와 북부에 위치한 두 곳의 포장에서 재배 수확되었다. 유전자 변형 고추에서 의 CMV-CP 단백질의 발현은 PCR법과 Southern blot을 통
해 고추내에 CMV-CP 유전자의 존재를 확인함으로 검증되 었으며(19), 농업적 재배특성 조사(20)가 확인되었고, 고추 로부터 발현 정제된 CMV-CP 단백질은 SDS-PAGE분석과 Western blot을 통해 $25 \mathrm{kDa}$ 크기 위치에서 확인되었다 (21).

고추 단백질 항원을 비교하기 위해 유전자변형 고추 및 그 모본 고추에서 단백질 항원을 추출하여 그 농도를 확인 하였다. 그 결과, 2008년도에 재배 수확된 고추의 경우 덕소 포장에서 재배 수확된 고추가 안성포장에서 재배된 고추보 다 높은 단백질 항원이 확인되었다(Table 2). 반면 2009년도 의 경우는 재배 지역에 상관없이 유전자변형 고추 H15보다 그 모본 P2377에서 높은 단백질 항원이 확인되었고, 2010년 도의 경우는 2009년도와는 정반대의 결과가 확인되었다. 이러한 지역별 연도별 일관성이 없는 결과를 통해 유전자변 형 고추와 그 모본사이에 유전자 변형으로 인한 고추 단백 질 항원의 농도에는 영향이 없음을 확인하였다.

또한 유전자변형 고추 $\mathrm{H} 15$ 와 그 모본 P2377에서 추출된 단백질 항원은 SDS-PAGE를 통해 단백질 항원의 분포가 비교 분석되었으며, 그 결과 고추에서 발현된 단백질의 양 상과 양은 재배 연도 및 환경적 영향에 따른 차이가 발견되 었지만, 동일한 연도에 재배된 유전자변형 고추와 그 모본 사이에서의 차이는 발견되지 않았다(Fig. 2).
(A)

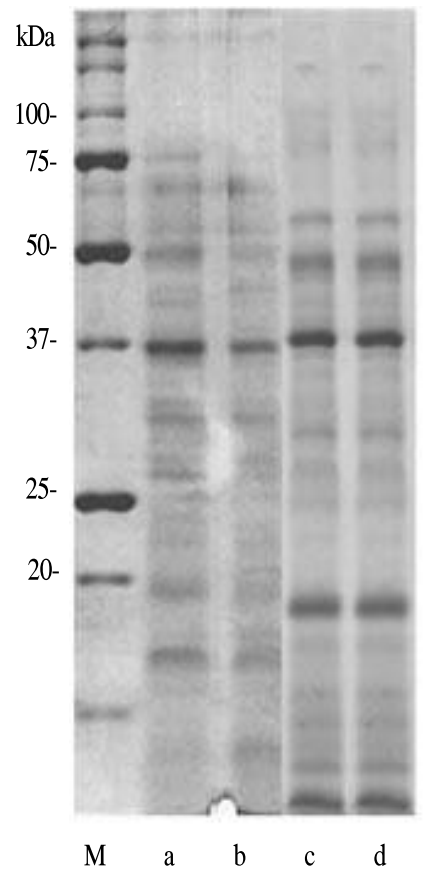

(B)

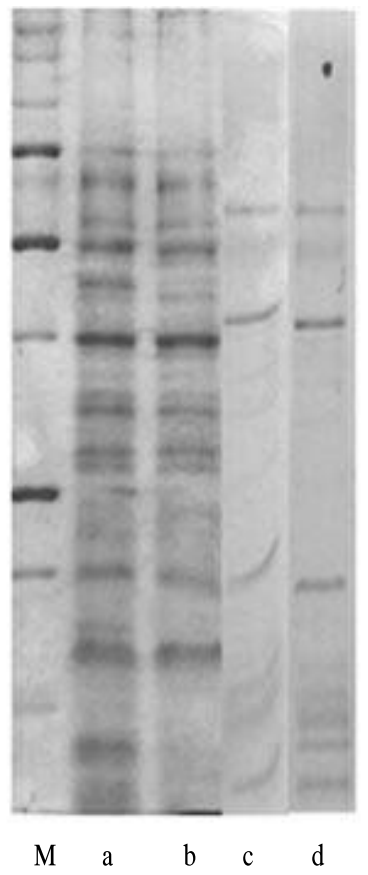

Fig. 2. Comparison of the protein bands of GM pepper and its non-transgenic parental control grown in Ansung (A) and Dukso (B).

Pepper extracts were separated by SDS-PAGE and stained by Coomasie brilliant blue Lane M, molecular weight marker; lane a, GM pepper in 2009; lane b, non-GM pepper in 2009; Lane c, GM pepper in 2010; lane d, non-GM pepper in 2010. 


\section{혈청 $\operatorname{lgE}$ 와의 항원-항체 반응성 비교}

유전자변형 및 그 모본 고추에서 추출된 고추 항원과 혈청 $\mathrm{IgE}$ 와의 반응성을 비교하기 위해 설문을 통해 알레르 기가 있다고 응답한 농우바이오(주) 연구소 종사자들의 개 별 혈청을 이용하여 immunoblotting 및 ELISA 실험을 진행 하였다. Immunoblotting법을 이용한 항원-항체 반응성 비교 에 사용된 5 명의 농우바이오(주) 종사자들과 1 명의 대조군 혈청 결과를 비교한 결과 사용된 개별 혈청에 따라 반응성 을 나타낸 밴드의 양상은 다르게 확인되었다(Fig. 3). 혈청 $\mathrm{NB}-1$ 의 경우 대략 $55 \mathrm{kDa}$ 과 $35 \mathrm{kDa}$ 위치에서 비교적 뚜렷 한 항원-항체 반응성이 확인되었고, NB-14 혈청의 경우 대략 $55 \mathrm{kDa}$ 위치에서만 비교적 뚜렷한 항원-항체 반응성 이 확인되었다. 혈청 NB-21의 경우 대략 $55 \mathrm{kDa}$ 위치에서 비교적 강한 항원-항체 반응성이 확인되었으며 대략 80 $\mathrm{kDa}$ 위치에서도 미약하나마 항원-항체 반응성이 확인되었 으며 대조군으로 사용된 건강한 사람의 혈청에서는 희미한 비특이적 반응성이 확인되었다. 조사된 모든 환자혈청의 경우 조사된 고추의 재배 장소(안성 또는 덕소) 및 $\mathrm{GM} / \mathrm{non}-\mathrm{GM}$ 에 따른 반응성의 차이가 없음이 확인되었다.

환자 혈청의 양 부족으로 인해 immunoblotting법을 이용 한 항원-항체 반응성 비교에는 총 3 명의 농우바이오(주) 연구소 종사자들의 혈청이 사용되었다. Immunoblotting 법 에서 확인된 결과와 마찬가지로 ELISA 실험 결과에서도 조사된 개별 혈청은 재배 지역(안성 또는 덕소)에 따른 반응 성의 차이가 없었으며, 유전자변형 고추와 그 모본에서의 항원-항체 반응성의 차이가 없는 것이 확인되었다(Fig. 4).
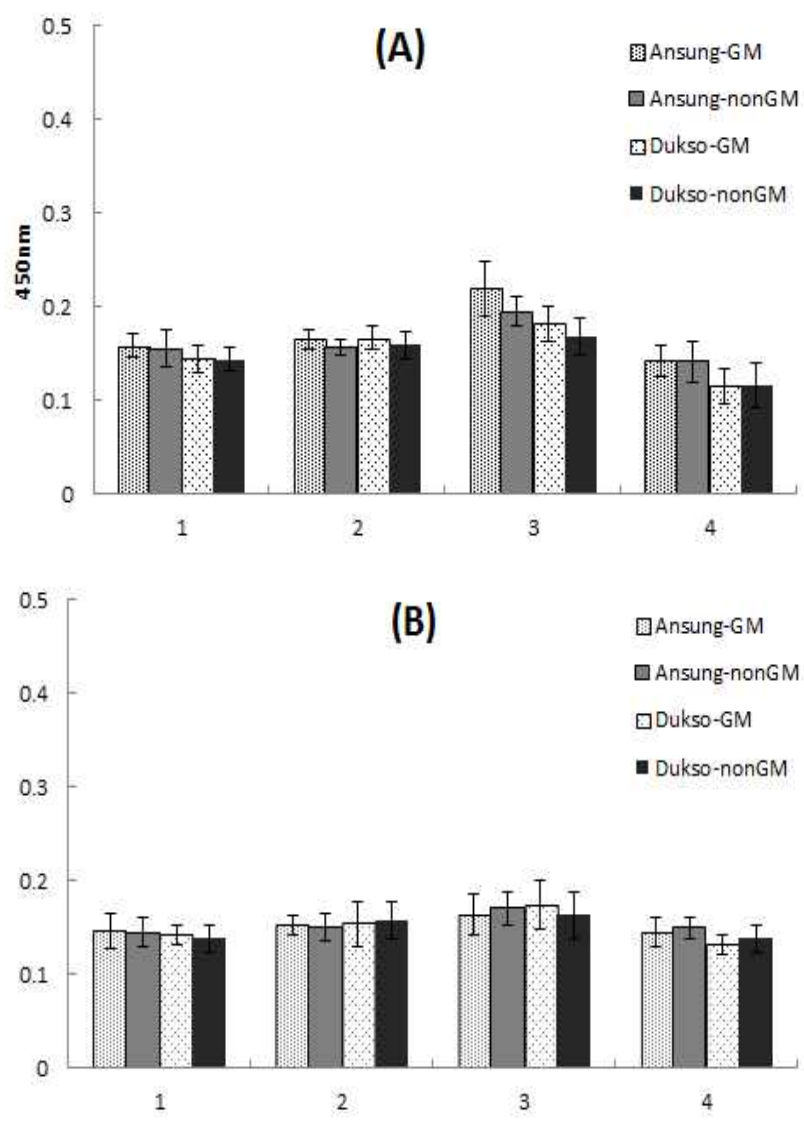

Fig. 4. Screening of sera with GM/non-GM pepper grown in 2009 (A) and 2010 (B) by ELISA.

Three patients sera (NB-4, NB-6 and NB-16) and one non-allergic serum were screened with GM pepper and its non-transgenic parental control grown in Ansung/Dukso. No. 1, NB-4; no. 2, NB-6;, no. 3, NB-16; no. 4, non-allergic serum.
NB-1

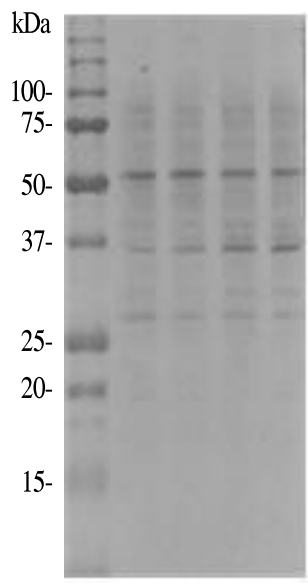

$\begin{array}{llllll}M & a & b & c & d\end{array}$
NB-4

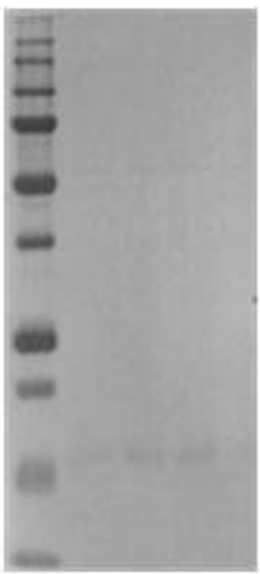

$\begin{array}{lllll}M & \text { a } & b & c & d\end{array}$
NB-14

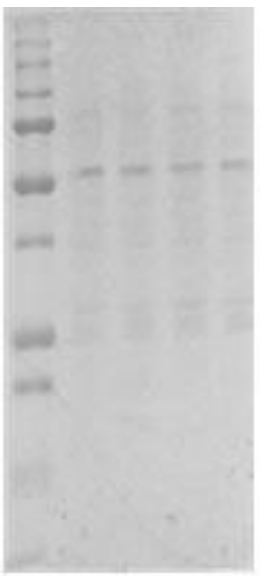

$\begin{array}{lllll}M & a & b & c & d\end{array}$

NB-18

NB-21

NA

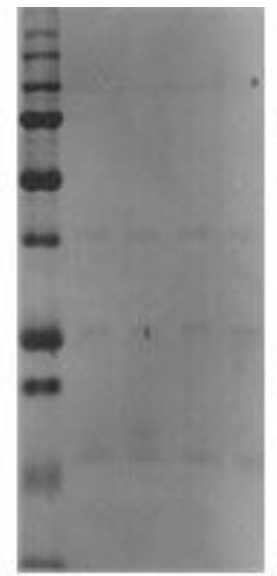

$\begin{array}{lllll}M & a & b & c & d\end{array}$

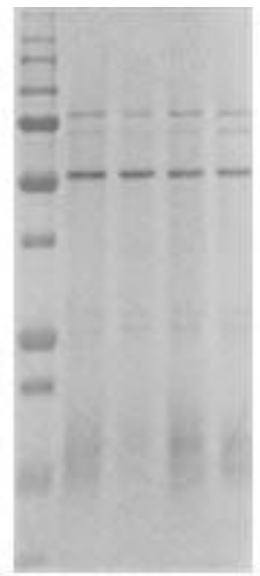

$\begin{array}{lllll}M & a & b & c & d\end{array}$

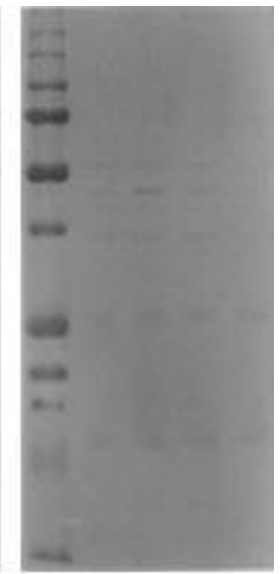

$\begin{array}{lllll}M & a & b & c & d\end{array}$

Fig. 3. Immunoblot detection of GM pepper and its non-transgenic parental control grown in 2010.

Five patients sera (NB-1, NB-4, NB-14, NB-18 and NB-21) and one non-allergic serum (NA) were used for immunoblot detection. Lane M, molecular weight marker; lane a, GM pepper grown in Ansung; lane b, non-GM pepper grown in Ansung; lane c, GM pepper grown in Dukso; lane d, non-GM pepper grown in Dukso. 
이상의 결과를 종합할 때, 유전자변형 고추 $\mathrm{H} 15$ 는 그 모본과 비교하여 형질전환으로 인한 알레르기성의 변화는 없는 것으로 판단된다.

\section{요 약}

$\mathrm{CMV}$ 바이러스 저항성 $\mathrm{H15}$ 고추 도입유전자의 발현산물 인 CMV-CP 단백질의 80 개씩의 아미노산 비교에서 $35 \%$ 보다 큰 상동성을 갖거나 8 개 이상의 일련된 아미노산 염기 서열이 일치하는 알레르겐은 존재하지 않는 것이 확인되었 으며, 따라서 CMV-CP 단백질 서열은 기지의 알레르겐과 구조적 및 면역학적으로 연관된 유사성이 없음을 확인하였 다. 형질전환에 따른 특성 변화를 비교하기 위해 서로 다른 지역에서 재배된 CMV 바이러스 저항성 H15 고추 및 그 모본의 발현 단백질 항원 농도와 그 분포를 비교한 결과 발현된 단백질의 양상과 양은 재배 연도 및 환경적 영향에 따른 차이가 발견되었지만, 동일한 연도에 같은 장소에서 재배된 유전자변형 고추와 그 모본 사이에서의 차이는 발견 되지 않아 형질전환으로 인한 특성변화는 없는 것으로 확인 되었다. 환자 혈청을 이용해 immunoblotting 법과 ELISA법 으로 확인한 항원-항체 반응성 비교에서도 $\mathrm{CMV}$ 바이러스 저항성 $\mathrm{H} 15$ 고추와 그 모본 P2377사이에 차이가 없는 것이 확인되었다. 이러한 결과를 종합할 때, 유전자변형 고추 $\mathrm{H} 15$ 는 그 모본과 비교하여 형질전환으로 인한 알레르기성 의 변화는 없는 것으로 판단된다.

\section{References}

1. IFT's Expert Panel on Food Safety and Nutrition (1985) Food Allergen and Sensitivities. Food Technol, 39, 65-71

2. Metcalfe D, Astwood J, Townsend R (1996) Assessment of the allergenic potential of food derived from genentically engineered crop plants. Crit Rev Food Sci Nutr, 36, 165-186

3. Gendel S (1998) Sequence databases for assessing the potential allergenicity of proteins used in transgenic foods. Adv Food Nutr Res, 42, 63-92

4. Son DY, Lee BR, Shon DW, Lee KS, Ahn KM, Nam SY, Lee SI (2000) Allergenicity change of soybean proteins by thermal treatment. Korean J Food Sci Tenchnol, 32, 959-963

5. Astood JD, Leach JN, Fuchs RL (1996) Stability of food allergens to digestion in vitro. Nat Biotechnol, 14, 1269-1273

6. Fu TJ, Abbott UR, Hatzos C (2002) Digestibility of food allergens and non-allergenic proteins in simulated gastric fluid and simulated intestinal fluid- a comparative study. J Agric Food Chem, 50, 7154-7160

7. Lee SH, Lee JB, Kim SM, Choi HS, Park JW, Lee JS, Lee KW, Moon JS (2004) The incidence and distribution of viral diseases in pepper by cultivation types. Res Plant Dis, $10,231-240$

8. Guil-Guerrero JL, Martínez-Guirado C, RebollosoFuentes M del Mar, Carrique-Pérez A (2006) Nutrient composition and antioxidant activity of 10 pepper (Capsicum annuum) varieties. Eur Food Res Technol, 224, 1-9

9. Lee JH, Hong JS, Ju HJ, Park DH (2015) Occurrence of viral diseases in field-cultivated pepper in Korea from 2006 to 2010. Korean J Organic Agri, 23, 123-131

10. Kim DH, Cho JD, Kim JH, Kim JS, Cho EK (2005) Ultrastructural characteristics of necrosis and stunt disease in red pepper by the mixed infections of Tobacco mosaic virus-U1 and Pepper mild mottle virus and Pepper mottle virus. Plant Pathol J, 21, 252-257

11. Alonso E, Gracia LI, Avila RMJ, Wicke B, Serra MYT, Diaz RJR (1989) A tobamovirus causing heavy losses in protected pepper crops in Spain. J Phytopathol, 125, 67-76

12. Pares RD (1985) A tobamovirus infecting capsicum in Australia. Ann Appl Biol, 106, 459-474

13. Schuerger AC, Hammer W (1995) Effects of temperature on disease development of tomato mosaic virus in Capsicum annuum in hydroponic systems. Plant Dis, 79, 880-885

14. Lee YH, Jung M, Shin SH, Lee JH, Choi SH, Her NH, Lee JH, Ryu KH, Paek KY, Harn CH (2009) Transgenic peppers that are highly tolerant to a new CMV pathotype. Pant Cell Rep, 28, 223-232

15. Bradford M (1976) A rapid and sensitive method for the quantitation of microgram quantities of protein utilizing the principle of protein-dye binding. Anal Biochem, 72, 248-254

16. Laemmli UK (1970) Cleavage of structural proteins during the assembly of the head of bacteriophage T4. Nature, 227, 680-685

17. Codex Alimentarius (2009) Foods derived from modern biotechnology. Codex Alimentarius Commission, Joint FAO/WHO Food Standards Programme, Food and Agriculture Organization of the United Nations, Rome, Italy

18. Hileman RE, Silvanovich A, Goodman RE,Rice EA, 
Holleschak G, Astwood JD, Hefle SL (2002) Bioinformatic methods for allergenicity assessment using a comprehensive allergen database. Int Arch Allergy Immunol 128, 280-291

19. Lee YH, Jung M, Shin SH, Lee JH, Choi SH, Her NH, Lee JH, Ryu KH, Paek KY, Harn CH (2009) Transgenic peppers those are highly tolerant to a new CMV pathotype. Plant Cell Rep, 28, 223-232

20. Cho DW, Oh JP, Park KW, Chung KH (2009) Analysis of agricultural characteristics for the virus resistant GM pepper plants grown in three different regions in Korea. Korean J Hort Sci Technol, 27, 521-529

21. Bang SN, Jung YS, Eom SJ, Kim GB, Chung KH, Lee GP, Son DY, Park KW, Hong JS, Ryu KH, Lee C (2012) Assessment of the cucumber mosaic virus coat protein by expression evaluation in a genetically modified pepper and Escherichia coli BL21. J Food Biochem, 36, 432-440 